\title{
Study of the impact of the discharges of the Vila-Viçosa small hydroelectric development (Portugal) on the water quality and on the fish communities of the Ardena river
}

\author{
G. R. Tavares ${ }^{1}$, N. Formigo ${ }^{2} \&$ T. Jesus ${ }^{3}$ \\ ${ }^{1}$ Escola Secundária de Arouca. Av dos Descobrimentos, $n^{\circ} 3,4540-104$ Arouca. \\ E-mail: comenda@mail.pt \\ ${ }^{2}$ Departamento de Zoologia-Antropologia, Faculdade de Ciências da Universidade do Porto - Praça Gomes \\ Teixeira s/n, 4099-002 Porto, E-mail: neformig@fc.up.pt \\ 3 Universidade Fernando Pessoa; Rua da Constituição, 56 5 , 4200-191 Porto; \\ E-mail: tmjesus@sapo.pt ou tjesus@ufp.pt
}

\begin{abstract}
A study of the Vila-Viçosa small hydroelectric development, situated on the Ardena river (hydrographical basin of the river Douro, Portugal) was carried out for one year, with the purpose of evaluating the existence of differences in the fish communities found downstream and upstream of the development. A characterization of the system was made, bearing in mind morphological, hydrological and physical and chemical characteristics and studying the structure and dynamics of the fish communities. With the collected data on physical and chemical parameters a study of its space-time variation was made. Moreover, with the data relative to the fish communities a study of the space-time variation of some parameters was carried out.

After the analysis of the data, it is possible to conclude that the Ardena river is a lotic system with water of good quality and that the functioning of the hydroelectric plant does not produce variations of the values of the parameters measured. The results obtained for the space-time variation of the fish community reveal some alterations in its distribution.
\end{abstract}

Key Words: environmental impact, small hydroelectric developments, fish

\section{RESUMEN}

Durante un año se ha estudiado la minicentral hidroeléctrica de Vila Viçosa en el río Ardena (cuenca del Duero, Portugal), con el objetivo de evaluar la existencia de diferencias en las comunidades de peces situadas abajo y arriba de la minicentral hidroeléctrica, caracterizando el sistema desde el punto de vista morfológico, hidrológico y físico-químico y estudiando la estructura y dinámica de las comunidades de peces.

Con los datos relativos a los parámetros físico-químicos y los peces se ha hecho el estudio de la variación espacio-temporal. Además con los datos de los peces se ha estudiado la variación espacial y temporal de algunos parámetros.

Después de analizados los datos, se puede decir que el río Ardena es un sistema lotico con agua de buena calidad y que el funcionamiento de la minicentral no provoca alteraciones de los valores encontrados. Los resultados de la variación espacial y temporal de la comunidad de peces reflejan alteraciones en su distribución.

Palabras clave: impacto ambiental, minicentrales hidroeléctricas, peces

\section{INTRODUCTION}

Small hydroelectric plants are hydroelectric developments, which have seen a great increase in Portugal, from the 1980's onwards. This increase was duo to the creation of incentives to the production of electrical energy in the private sector, added to by the search for alternative forms of energy production, less harmful to the environment (Costa, 1997)

At present, the coming into effect of the new communitarian legislation demanded the closing of the enterprises that didn't obey the working norms demanded by the legislation. These hydroelectric plants of small dimensions, can work by water trickle and have small lagoons, which 
accumulate water according to the daily torrent regime of the rivers where they are situated.

The small hydroelectric plants lead to modifications of physical character in the aquatic ecosystems and consequently on the dynamics of the biological communities (Penczak, 1995; Ferreira et al., 1996). In this way, in what concerns the physical modifications, we can point out the flow, which conditions the water velocity, which in their turn leads to changes in the habitats and ecological niches of the different biotic communities. In the sequence of these modifications, there is a decrease of the effective of fish species, especially of the migrating ones, as well as an alteration in its space and time dynamics.

In this study we aimed at getting information about the space/time dynamics of the abiotic factors and of the fish community of the Ardena River, affluent of the right margin of the Paiva River (hydrographic basin of de Duero River), in the zone under the influence of the small hydroelectric plant (Fig. 1).

This river is a part of the a deep valley, of granitic-schistous nature, characterised by great torrent oscillations, depending on atmospheric conditions and on the discharge regime imposed by the working of the small hydroelectric deve- lopment. On marginal grounds, small extensive agricultural exploitations are predominant, as well as wooded areas, where there are essentially Eucalyptus (Tavares, 1999)

In this way, in the upper region, situated upstream of the small hydroelectric development reservoir, the river presents characteristics which are close to "natural", its hydrological regime being influenced either by climatic characteristics, or by the existence of several dams, from which irrigation canals start. In the lower region there are two distinct zones: the first, situated between the barrage and the hydroelectric central, in which the torrent is constant and reduced almost throughout the whole year, and the second, situated after the discharge central and characterised by a hydrological regime with great fluctuations, either daily or seasonally.

\section{CHARACTERIZATION OF THE ARDENA RIVER AND OF THE SAMPLING POINTS}

The Ardena River is a small watercourse with about $19 \mathrm{~km}$ of extension, which springs on the Montemuro Mountain as a small brook named

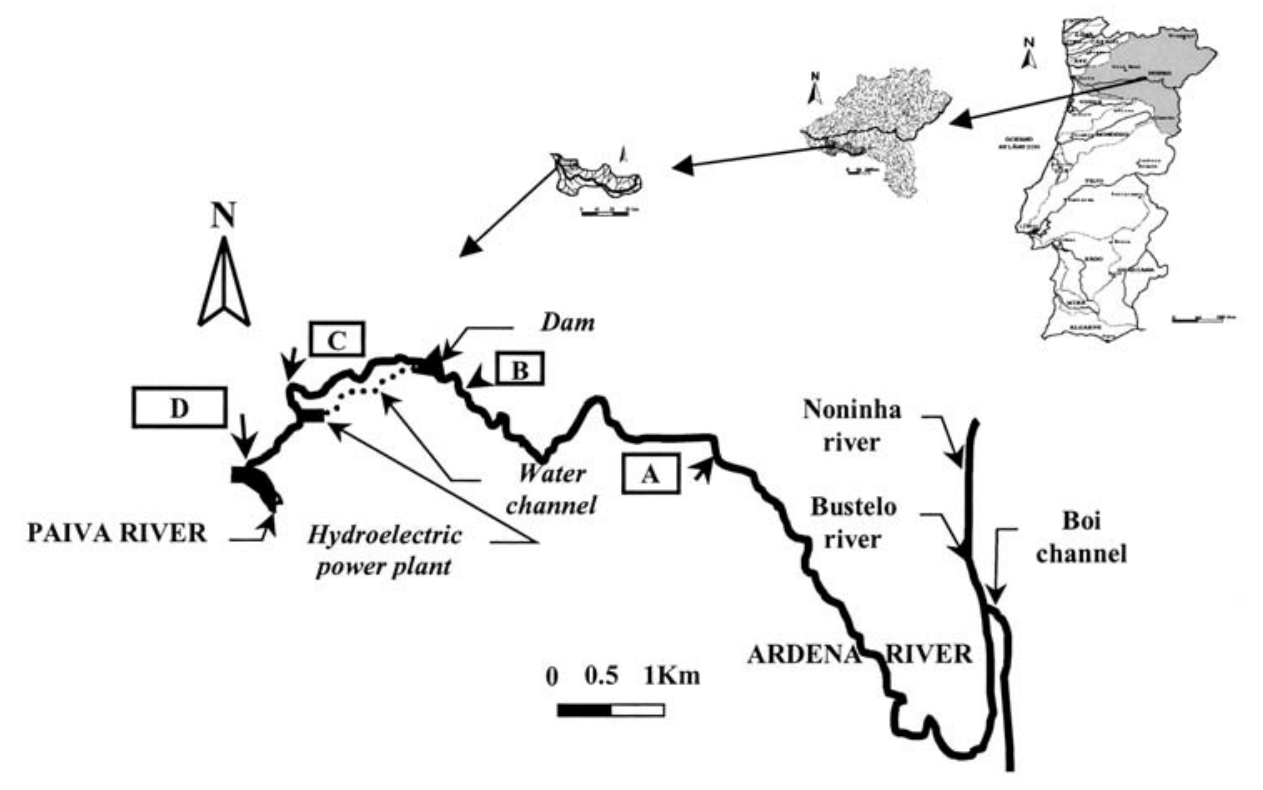

Figure 1. Sample points on Ardena River. Estaciones de muestreo en el río Ardena. 


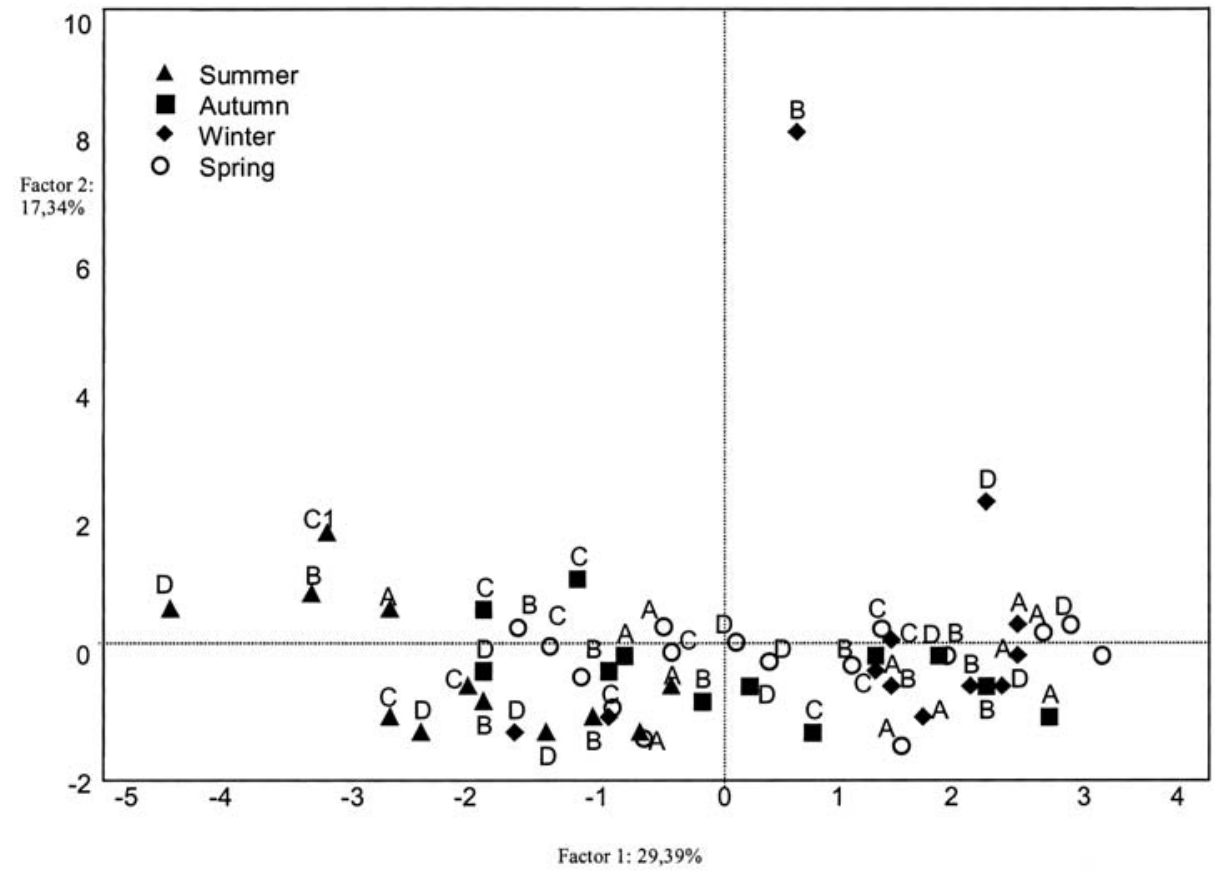

Figure 2. Sample ordination in all sample points for the main physical and chemical parameters analysis in the space formed by the two first factors of the principal components analysis (PCA) (explained variance: factor $1-20.9 \%$; factor $2-17.9 \%$ ). Ordenación de las muestras en todas las estaciones de muestreo según el análisis de los principales parámetros físico-químicos, en el espacio formado por los dos primeros factores del Análisis de Componentes Principales (PCA) (varianza explicada: factor 1 $-20.9 \%$; factor $2-17.9 \%$ ).

Noninha and which at about $3 \mathrm{~km}$ from the spring takes the name of Bustelo bank. Approximately $5 \mathrm{~km}$ from the spring there is a dam where most of the river water is deviated into a watering channel - "the drain of the ox" - which ends on the Paiva River. It is from this place on, that the watercourse formed by the non-deviated water and by the junction of waters from superficial spilling and from small lateral water lines, takes the name of Ardena River, which flows into the right margin of the Paiva River, running through a valley with a great slope. Throughout its course, it presents an alternation between rapids and zones of dead waters, due to either the natural topography of the ground or by the several little dams built for the deviation of the springs to watering channels. The Vila Viçosa small hydroelectric plant has been situated in the last $4 \mathrm{~km}$ of the river since 1993 (Fig. 1)
In the lagoon of the small hydroelectric plant, situated about $4.5 \mathrm{~km}$ from the mouth of the Ardena river, the water is retained, and is afterwards deviated through a derivation channel which runs parallel to the river into the hydroelectric central where after being turbinated it is returned to the original stream, about $1 \mathrm{~km}$ from the mouth, leading to great daily fluctuations on the hydrologic regime (Fig. 2 and Table 1).

The selection of the sampling points was made bearing in mind the location of each element of the small hydroelectric plant, having chosen four sampling points:

- Point A, situated upstream of the lagoon, where the torrent regime was the closest to "natural"as possible,

- Point B, immediately upstream of the lagoon, allowed us to verify whether the many dams existent throughout the river lead to altera- 
Table 1 - Main characteristics of each sample point of the Ardena River. Principales características de cada estación de muestreo del río Ardena.

\begin{tabular}{|c|c|c|c|c|c|}
\hline & Characteristics & $\begin{array}{c}\text { Point } \\
\text { A }\end{array}$ & $\begin{array}{c}\text { Point } \\
\text { B }\end{array}$ & $\begin{array}{c}\text { Point } \\
\text { C }\end{array}$ & $\begin{array}{l}\text { Point } \\
\text { D }\end{array}$ \\
\hline Length (m) & & 5 & 5 & 7.5 & 5 \\
\hline Hydrologic regime & & "Natural" & "Natural" & Artificial & Artificial \\
\hline \multirow{2}{*}{$\begin{array}{l}\text { Average flood } \\
\left(\mathrm{m}^{3} / \mathrm{s}\right)\end{array}$} & Drought season ${ }^{(1)}$ & 0.20 & 0.53 & 0.04 & 0.12 \\
\hline & Rainy season ${ }^{(2)}$ & 1.01 & 1.77 & 0.16 & 2.60 \\
\hline \multirow{2}{*}{$\begin{array}{l}\text { With } \\
(\mathrm{m})\end{array}$} & Minimal & 7.20 & 5.50 & 4.10 & 3.50 \\
\hline & Maximal & 9.50 & 9.10 & 6.30 & 9.60 \\
\hline \multirow{2}{*}{$\begin{array}{l}\text { Maximal depth } \\
\text { (m) }\end{array}$} & Lower flood & 0.35 & 0.65 & 0.55 & 0.30 \\
\hline & Higher flood & 0.65 & 1.00 & 0.80 & 0.65 \\
\hline
\end{tabular}

tions in the composition and structure of the biotic community;

- Point $\mathrm{C}$, between the barrage and the small hydroelectric central, where the river torrent is generally low throughout the whole year;

- Point D, downstream of the small hydroelectric central discharge and by the mouth of the Paiva.

\section{MATERIAL AND METHODS}

The study was developed throughout one year (from July 1997 to July 1998), in which samples were taken at four points (Fig. 1): tow in upstream of the reservoir (A, B), and tow before the lagoon of the hydroelectric central $(C, D)$

We proceeded to the monthly determination of several physical-chemical parameters by the methods described in Welch (1948), Strickland \& Parsons (1972) and APHA (1992): air and water temperature, $\mathrm{pH}$, conductivity, flow, ammonia concentration, nitrites, nitrates, phosphates, dissolved oxygen, Biochemical Oxygen Demand $\left(\mathrm{BOD}_{5}\right)$, alkalinity and hardness (Table 2).

The sampling of the fish community was done every three months (July and November 1997, February and May 1998) in every sam- pling point, using electrical fishing as the method of capture (Cortes, 1989). After the collection, the specimens were identified, measured and weighted, and scales were also collected for posterior age determination.

With the data related to the chemical parameters, a principal components analysis (PCA) was performed to identify the existence of some patterns of space and time variation, followed by a discriminant analysis with the samples grouped by season of the year, in order to compare the existence of a seasonal distribution of the samples. Both analyses were made with the STATISTICA 6.0 program, after the standardization of the data $(\mathrm{X}=(\mathrm{X}-\mathrm{X}) / \mathrm{sd} \mathrm{x})$, in order to reduce the variability between the variables imposed by the different units in which they are measured (Clarcke \& Warwick, 1984).

With the collected data from the fish community, a study on the space-time variation of their distribution and abundance parameters was performed. For its representation, we used circular graphs in percentage made with the STATISTICA 6.0. As to the age structure, we decided to use point graphs for each species, with the exception of the eel, while for the length variations, graphs of the "Box-and-Wisker-Plot" type were used, using the EXCEL 5.0 program. 
Table 2 - Abiotic parameters analysed on the samples points of the Ardena River, their methods, units and bibliography references. Parámetros abióticos analizados en las estaciones de muestreo del río Ardena, metodologías, unidades y referencias bibliográficas.

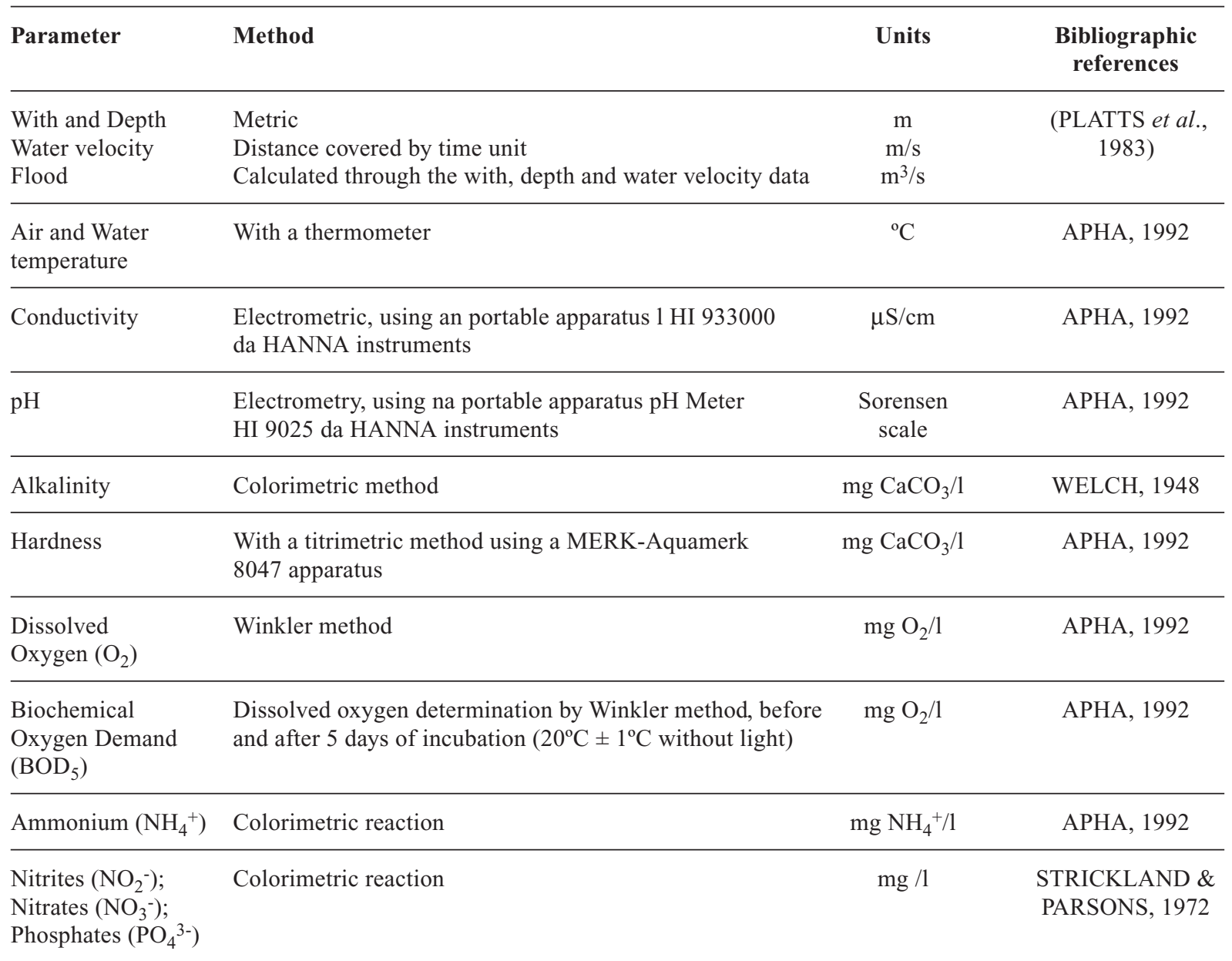

\section{RESULTS AND DISCUSSION}

The analysis of the distribution of the samples in the space defined by the two first factors of the principal components analysis (explained variance of $46,73 \%$ ), shows that the working of the small hydroelectric plant does not significantly influence the physical and chemical quality of the water. However, the sample distribution collected throughout the first factor $(29,39 \%$ of the variance) indicates a seasonal character in the variation of these parameters, which seems to be explained by the natural variations of the air and water temperature, as well as of the torrent, which reverberate in factors such as $\mathrm{pH}$, hardness, conductivity, alkalinity and dissolved oxygen concentration. (Figs. 2 and 3).

The $\mathrm{pH}$, conductivity, alkalinity and hardness present higher values during the hottest months, which can be related to the fact that it is also in these months that the flow is most reduced, leading to a greater sediment accumulation and an increase of the primary productivity (Peckarsky et al., 1990). The oxygen content is inversely related to the temperature and directly related to the flow, once the temperature increases the solubility of the oxygen decreases and so does the torrent, which reduces the turbulence of the water courses 


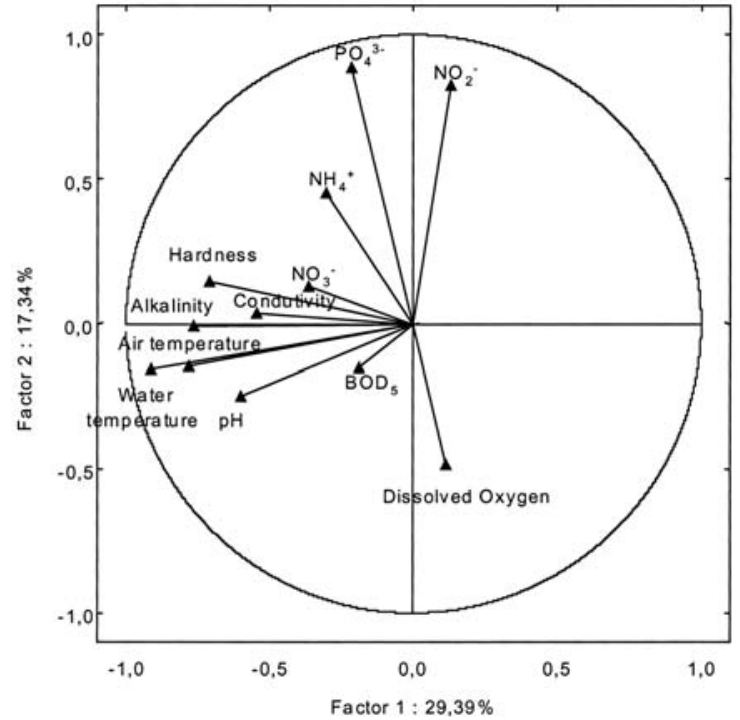

Figure 3. Representation of the correlation circle of the physical and chemical parameters determined with the two first axis of PCA. Representación del circulo de correlación de los parámetros físico-químicos determinado con los dos primeros ejes del PCA.

(Fig. 3). Along with these factors, an increase of the metabolic rate of the aquatic organisms takes place, which leads to an increase of oxygen consumption (Giller \& Malmqvist, 1998).

In order to confirm the previously obtained results, a discriminant analysis was made, grou-

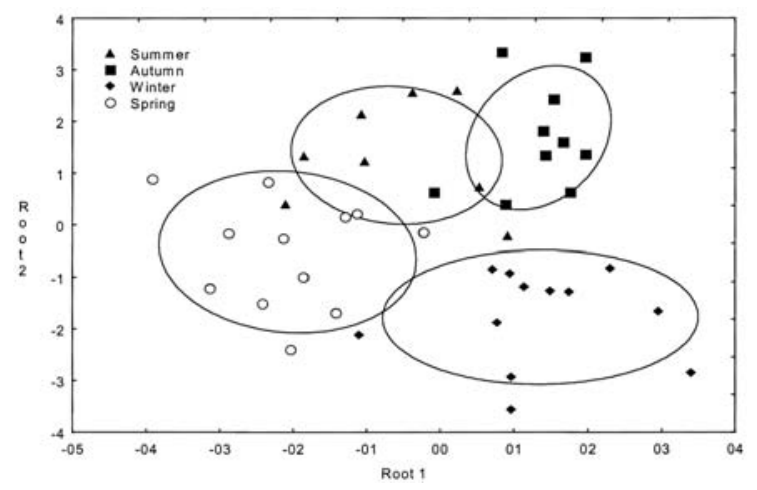

Figure 4. Graphic representation of the discriminant analysis showing the distribution of the collected samples grouping by seasons on the plane of two principals axis (root 1 and root 2). Discriminant function: $\mathrm{y}=-0.69$ air temperature $-0.60 \mathrm{NO}_{3}{ }^{-}$0.45 air temperature $+0.29 \mathrm{O}_{2}+0.27 \mathrm{pH}+0.26$ conductivity $+0.22 \mathrm{NO}_{2}{ }^{-}$. Representación gráfica del análisis discriminante mostrando la distribución de las muestras recogidas agrupadas por estaciones del año en el plano de los dos ejes principales (root 1 y root 2). Función discriminante: $y=-0.69$ temperatura aire $-0.60 \mathrm{NO}_{3}{ }^{-}-0.45$ temperatura aire +0.29 $\mathrm{O}_{2}+0.27 \mathrm{pH}+0.26$ conductividad $+0.22 \mathrm{NO}_{2}^{-}$.

ping the samples by seasons of the year (Fig. 4). In fact the samples collected in the summer (July, August and September) and in the winter (January, February and March) were in an opposite situation, while the samples collected in the autumn and spring occupied an intermediate
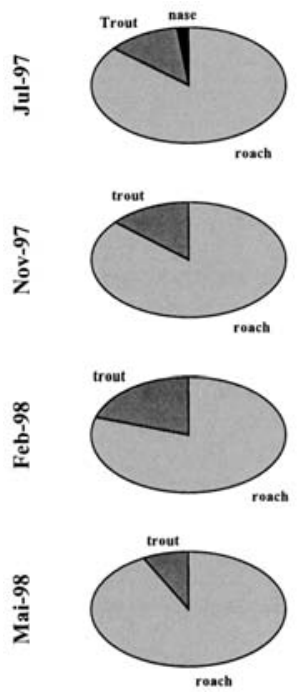

A
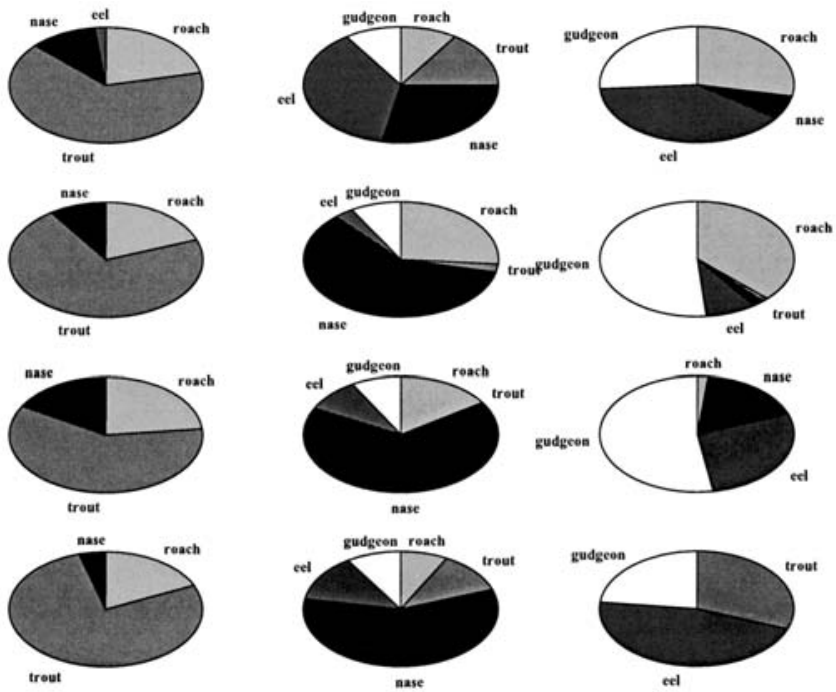

C

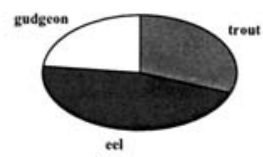

D

Figure 5. Spatial and temporal variation of the fish abundance. Variación espacial y temporal de la abundancia de peces. 
Table 3. Average, minimum, maximum and standard deviation of the physical and chemical parameters of each sample point. Media, mínimo, máximo y desviación estándar de los parámetros físico-químicos de cada estación de muestreo.

\begin{tabular}{|c|c|c|c|c|c|c|c|c|c|c|c|c|c|}
\hline & & 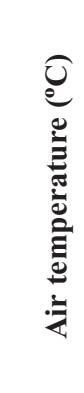 & 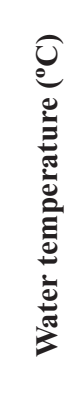 & 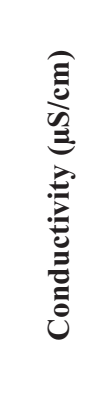 & $\frac{\pi}{2}$ & 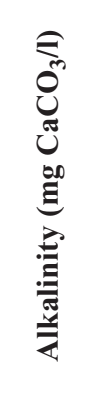 & 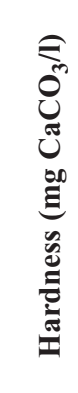 & 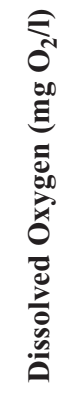 & 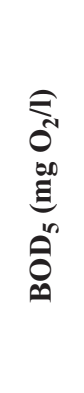 & 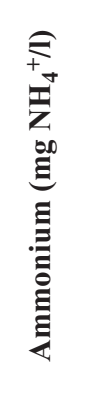 & 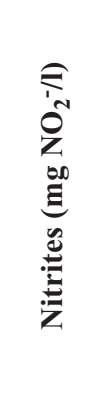 & 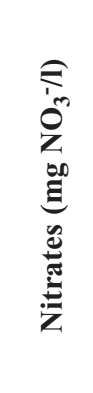 & 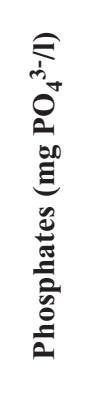 \\
\hline \multirow[t]{4}{*}{ Point A } & Max & 33.0 & 18.0 & 54.7 & 7.2 & 11.0 & 19.0 & 17.6 & 2.07 & 0.008 & 0.006 & 4.934 & 0.053 \\
\hline & Aver & 17.6 & 12.0 & 33.9 & 6.9 & 8.3 & 8.7 & 10.6 & 1.09 & 0.003 & 0.001 & 2.588 & 0.014 \\
\hline & Min & 9.0 & 8.0 & 23.7 & 6.5 & 5.0 & 5.0 & 8.1 & 0.05 & 0.000 & 0.000 & 1.367 & 0.000 \\
\hline & $\mathrm{Sdx}$ & 9.02 & 3.38 & 9.37 & 0.25 & 2.4 & 4.0 & 2.4 & 0.66 & 0.003 & 0.002 & 0.926 & 0.016 \\
\hline \multirow[t]{4}{*}{ Point B } & Max & 35.0 & 18.0 & 57.3 & 7.6 & 11.00 & 23.0 & 12.9 & 1.92 & 0.020 & 0.053 & 4.890 & 0.186 \\
\hline & Aver & 19.1 & 13.0 & 42.2 & 7.0 & 8.25 & 9.5 & 10.6 & 0.95 & 0.006 & 0.005 & 3.140 & 0.032 \\
\hline & Min & 10.0 & 9.0 & 30.7 & 6.3 & 5.00 & 4.0 & 8.9 & 0.15 & 0.000 & 0.000 & 1.583 & 0.000 \\
\hline & $\mathrm{Sdx}$ & 9.42 & 3.1 & 9.07 & 0.3 & 1.81 & 5.5 & 1.1 & 0.52 & 0.007 & 0.015 & 0.837 & 0.051 \\
\hline \multirow[t]{4}{*}{ Point C } & Max & 32.0 & 20.0 & 68.00 & 7.5 & 16.00 & 17.0 & 13.1 & 5.31 & 0.017 & 0.001 & 5.287 & 0.090 \\
\hline & Aver & 17.6 & 13.8 & 54.68 & 6.9 & 10.75 & 12.2 & 10.7 & 1.59 & 0.005 & 0.002 & 2.879 & 0.023 \\
\hline & Min & 5.0 & 8.0 & 39.20 & 6.2 & 7.00 & 8.0 & 8.4 & 0.38 & 0.000 & 0.000 & 1.678 & 0.000 \\
\hline & $\mathrm{Sdx}$ & 8.2 & 3.9 & 8.91 & 0.3 & 2.98 & 3.2 & 1.3 & 1.30 & 0.006 & 0.002 & 1.040 & 0.0272 \\
\hline \multirow[t]{4}{*}{ Point D } & Max & 36.0 & 20.0 & 66.30 & 7.5 & 21.00 & 18.0 & 13.9 & 2.27 & 0.010 & 0.027 & 5.550 & 0.060 \\
\hline & Aver & 18.9 & 13.6 & 43.54 & 6.9 & 9.91 & 10.9 & 10.9 & 1.21 & 0.004 & 0.003 & 2.964 & 0.010 \\
\hline & Min & 10.0 & 8.0 & 29.20 & 6.3 & 4.00 & 6.0 & 9.42 & 0.07 & 0.000 & 0.000 & 1.301 & 0.000 \\
\hline & $\mathrm{Sdx}$ & 8.65 & 4.1 & 12.63 & 0.3 & 4.67 & 5.1 & 1.4 & 0.70 & 0.004 & 0.007 & 1.036 & 0.019 \\
\hline
\end{tabular}

situation. The analysis of the discriminant function shows that factors such as air and water temperature and nitrates are the main ones responsible for the variations in the values obtained for the physical-chemical parameters.

The physical and chemical parameters analysed in this fragment of the Ardena River present values within a range which is suitable for good water quality (Tavares, 1999): with weak mineralization and low productivity, with characteristics which favour the normal development of the aquatic life, and even presenting conditions for the development of recreational and balneal activities (Table 3) (Nisbet \& Verneaux, 1970; Giller \& Malmqvist, 1998). On the other hand, there were no significant spatial differences registered which could be directly related to the small hydroelectric central.

The fish community of the Ardena River is made of a reduced number of species, with a particular spatial distribution, although relatively stable. Through the global analysis of the results obtained, it is possible to observe the existence of distinct populations upstream and downstream of the small hydroelectric plant (Fig. 5) (Welcome, 1985).

Thus, in the sampling points situated upstream of the lagoon (A, B) there is a predominance of the roach (Leuciscus cephalus) and the trout (Salmo trutta fario), whose age structures and growth parameters (Tavares, 1999) seem to indicate that they are stable resident populations 

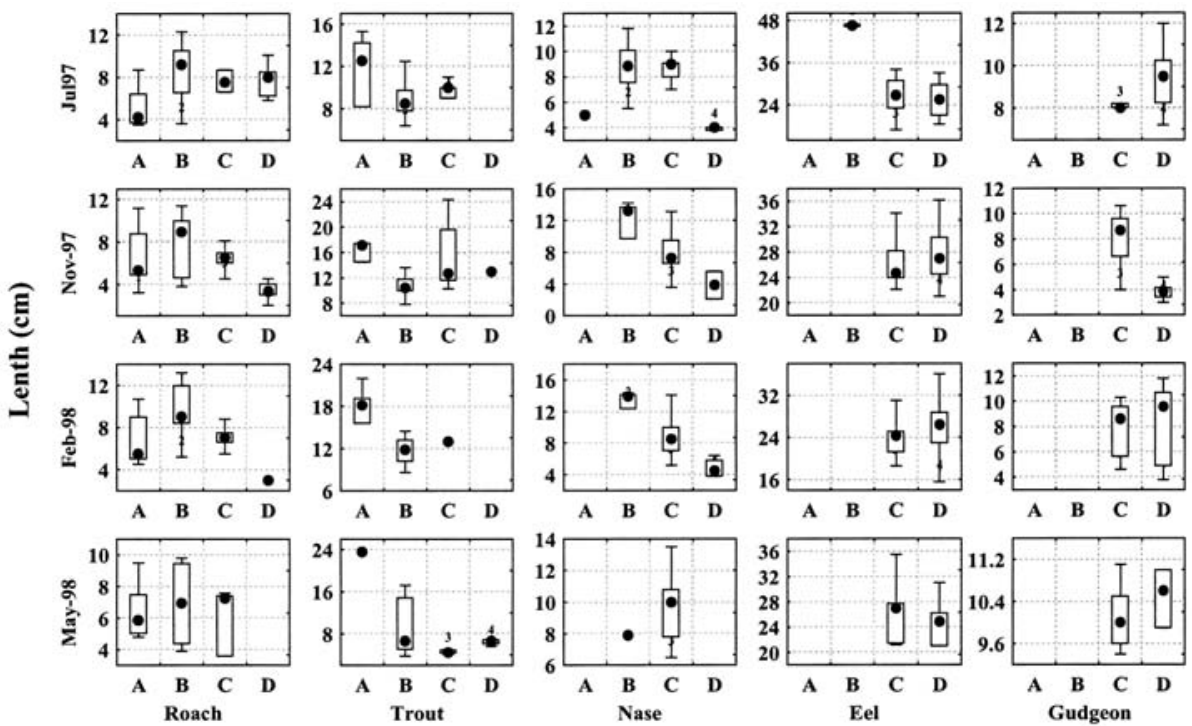

Figure 6. Spatial and temporal variation of the length of the organisms present on the fish community. Variación especial y temporal de la longitud de los individuos presentes en la comunidad de peces.

(Fig. 6). This fact is shown in the variability of the age structure of the specimens found in this river zone, were older (ages between $3+$ and $4+$ ) and longer specimens are predominant.

In July 1997, at point B, two eels (Anguilla anguilla) were found. Due to its dimension it is believed that they lived in that spot before and during the dam construction and because of this fact they were not able to explore the region downstream the lagoon.

In the zones situated downstream of the barrage $(C$ and $D)$ there is an increase of the specific diversity of the fish community, in which the predominant species are the nase (Chondrostoma polylepis duriensis), in the zone situated between the lagoon and the discharge place, and the eel (Anguilla anguilla) and gudgeon (Góbio gobio) in the region downstream of the discharge (Tavares, 1999).

The analysis of the growth parameters (Fig. 6), as well as of the age structure, seems to suggest that this is a more variable population group, influenced either by the proximity of the Paiva River, or by the dislocations of the different species throughout this section of the river, according to its reproductive season. This zone also seems to constitute a possible refuge zone from the torrents of the Paiva River during the rain season. In fact, the specimens found are of ages inferior to $2+$ and are shorter than the specimens found in the upper regions (Tavares, 1999).

Thus, the composition of the fish community downstream of the small hydroelectric plant seems to be conditioned simultaneously by two factors: the proximity of the Paiva River and the flow regime imposed by the working of the small hydroelectric plant (Formigo \& Sousa, 1994; Margalef, 1983; Hynes, 1970). The greatest impact of the small hydroelectric plant is in the downstream populations, which can be related to the decrease of the flow between the lagoon and the central, in addition to a great instability of the torrent regime registered between the central and the mouth of the river. It should be pointed that this study did not allow for the evaluation of the magnitude of the impacts, since there were no previous studies that would allow the comparison of the different biotical communities.

This way, throughout the river it is possible to define the existence of two distinct zones, which are isolated from each other. However, other studies are needed to genetically characterise the populations upstream and downstream of the small hydroelectric plant. 


\section{CONCLUSIONS}

Based on the results presented, and keeping in mind the inexistence of previous studies on this river and about this kind of enterprise, the conclusions presented here are exclusively the result of the interpretation of the fish community and of the results given by the physical and chemical parameters.

The Ardena River is a water course that presents a good water quality, with weak mineralization, low productivity and no apparent pollution, that allows for the maintenance and development of aquatic life.

The impact of the working of the small hydroelectric plant affects in a different way the fragments situated between the barrage and the central discharge and in the fragments situated downstream of the same. This means however, and in both cases, a decrease in water quality and an alteration of the structure and composition of the fish communities (Tavares, 1999).

In the places upstream of the lagoon, the roach (Leuciscus cephalus) and the trout (Salmo trutta fario) are predominant, while in the point between the lagoon and the discharge the nase (Chondrostoma polylepis durienses) is predominant, as are the gudgeon (Góbio gobio) and the eel (Anguilla anguilla) downstream of this point. These populations seem to be more stable and self-sustained, being influenced mainly by the succession of dams and by the existence of an irrigation drain, which deviates a significant part of the torrent.

The populations downstream of the small hydroelectric plant seem to be less stable, presenting a greater variability in the specific composition of the fish community, which, among other factors, can be explained by the movement of individuals coming from the fish community of the Paiva River, and also conditioned by the daily and seasonal variation of the torrent that influences this zone.

In general terms, the small hydroelectric plant has an influence on the distribution of the fish community, building a barrier that prevents the displacement of the individuals of this community between several zones of the river. However, one cannot exclude the fact that this watercourse has natural features, which can also be based on the discontinuities of the fish community, namely the succession of dams and the waterfalls.

\section{BIBLIOGRAPHY}

ALBA-TERCEDOR, J. y A. SANCHÉZ-ORTEGA. 1988. Un método rápido y simple para evaluar la calidad biológica de las aguas corrientes basado en el de Hellawell (1978). Limnetica, 4: 51-56

APHA.1992. Standard Methods for the Examination of Water and Wastewater. $18^{\circ} \mathrm{ed}$.

APMH. 1997. Rendibilidade de um pequeno aproveitamento hidroeléctrico nas actuais condições de mercado. Simpósio sobre Aproveitamentos Hidroeléctricos, 1997, Lisboa, Portugal.

ARMITAGE, P. D. \& I. PARDO. 1995. Impact assessment of regulation at the reach level using macroinvertebrate information from mesohabitats. Regulated Rivers: Research \& Management 10 : $147-158$

ARMITAGE, P. D., I. PARDO. \& A. BROWN. 1995. Temporal constance of fauna assemblages in "mesohabitats". Application to management? Archiv. Hydrobiol., 133: 67-387

BOULTON, A. J., C. G. PETERSON, N. B. GRIMM, \& S. G. FISHER. 1992. Stability of an aquatic macroinvertebrate community in a multiyear hidrologic disturbance regime. Ecology, 73: 21922207

CAMPAIOLI, S., P. F. GHETTI, A. MINELLI \& S. RUFFO. 1994. Manuale per il riconoscimento dei Macroinvertebrati delle acque dolci italiane, Vol.I. Provincia Autonoma di Trento. $357 \mathrm{pp}$

CLARCKE, K. R. 1993. Non-parametric multivariate analyses of changes in community structure. Aust. J. Ecol., 18: 117-143

CLARCKE, K. R. \& R. H. GREEN. 1988. Statistical design and analysis for a "biologist effects" study. Mar. Ecol. Prog. Ser., 46: 213-226

CLARCKE, K. R., R. M. WARWICK, \& B. E. BROWN. 1993. An index showing breakdown of seriation related to disturbance, in a coral-reef assemblage. Nar. Ecol. Prog. Ser., 102: 153-160

CLARCKE, K. R. \& R. M. WARWICK. 1994. Change in marine communities: an approach to 
statistical analysis and interpretation. Plymouth Marine Laboratory, UK

COBB, D. G., T. D. GALLOWAY, \& J. F. FLANNAGAN. 1992. Effects of discharge and substrate stability on density and species composition of stream insects. Can. J. Fish. Aquat. Sci., 49: 17881795

COSTA, A. S. 1997. Mini-hídricas em Portugal: passado, presente e fúturo. Simpósio sobre "Aproveitamentos Hidroeléctricos". 1997, Lisboa, Portugal.

DE PAUW, N. \& G. VANHOOREN. 1983. Method for biological quality assessment of watercourses in belgium. Hydrobiologia, 100: 153-168

DEATH, R. G. \& M. J. WINTERBOURN. 1994. Environmental stability and community persistence: a multivariate perspective. $J$. of the North Am. Benthol. Soc., 13: 125-139

E.P.A. 1999. Rapid bioassessment protocols for use in streams and wadeable rivers: periphyton, benthic macroinvertebrates and fish. $2^{\text {nd }}$ ed. United States, $5.1-5.33,7.1-7.34$

FIELD, J. G., K. R. CLARCKE, \& R. M. WARWICK. 1982. A practical strategy for analysing multispecies distribution patterns. Mar. Ecol. Prog. Ser., 8: 37-52

GASITH, A \& V. H. RESH. 1999. Streams in mediterranean climate regions. Abiotic influences and biotic responses to predictable seasonal events. Annu. Rev. Ecol. Syst., 30: 51-81

GILLER, K. W. \& B. MALMQVIST. 1998. The biology of streams and rivers. Oxford University Press, England, 296 pp

GRZYBKOWSKA, M. 1991. Development and habitat selection of Chironomidae communities. Regulated Rivers: Research \& Management, 6: 257-264

HAUER, F. R. \& G. A. LAMBERTI. 1996. Methods in stream ecology. Academic Perss. 674 pp.

HERRMANN, J. \& C. SAHLÉN. 1999. Stream invertebrate communities responding seasonal droughts. Abstracts Book of the Symposium on Assessing the Ecological integrity of running waters. 1999, Vienna, Austria: p34

JESUS, T. 2001. Centrais hidroeléctricas de pequena dimensão: impacto na dinâmica da comunidade de macroinvertebrados bentónicos e na variação da qualidade da água (Mini-hídrica de Vila Viçosa e "Cascata" do Alva). Dissertação de doutoramento apresentado à Faculdade de Ciências da Universidade do Porto. 235 pp.
KARR, J. R. 1999. Defining and measuring river health. Freshwat. Biol., 41: 221-234

KEFFORD, B. J. \& P. S. LAKE. 1999. Effects of spatialand temporal changes in water velocityon the density of the freshwater snail Potamopyrgus antipodarum (Gray). Molluscan Research, 20(1): 1116

LANCASTER, J. 1999. Small-scale movements of lotic macroinvertebrates with variations in flow. Freshwat. Biol., 41: 605-619

LUDWIG, J. A. \& J. F. REYNOLDS. 1988. Statistical Ecology. A primer on methods and computing. John Wiley \& Sons, Inc. 337 pp

MATTHAEI, C. D., U. UEHLINGER, E. I. MEYER \& A. FRUTIGER. 1996. Recolonization of benthic invertebrates after experimental disturbance in a Swiss prealpine river. Freshwat. Biol., 35: 233-244

MATTHAEI, C. D., D. WERTHMULLER \& A. FRUTIGER. 1997. Invertebrate recovery from a bed-moving spate: the role of drift versus movements inside and over substratum. Archiv Hydrobiol., 140: 221-235

MILLAN A., J. L. MORENO y J. VELASCO. 1997. Coleópteros y Heterópteros acuáticos del complejo lagunar del río Arquillo (Albacete). Separata de Albacete. Revista de Estudios Albacetenses, 40: 169

MONTEIRO, T. J. 1996. Incidências ambientais dos aproveitamentos hidroeléctricos. Ingenium, 10: 68-73

MUNNÉ, A., C. SOLÁ y N. PRAT. 1998. QBR: Un índice rápido para la evaluación de la calidad de los ecossitemas de ribera. Tecnología del Agua, 175: $20-37$

NISBET, M. et J. VERNEAUX. 1970. Composantes chimiques des eaux courantes - discoussion et proposition de classes en tant que bases d'interpretation des analyses chimiques. Annls. Limnol., 6(2): 161-190

PALMER, M. A. \& N. L. POFF. 1997. The influence of environmental heterogeneity on patterns and processes in stream. J. North Am. Benthol. Soc., 16: 169-173

PECKARSKY, B. L., S. C. HORN \& B. STATZNER. 1990. Stonefly predation along a hydraulic gradient: a field test of the harsh-benign hypothesis. Freshwat. Biol., 24: 181-191

PLATTS, W. S., W. F. MEGAHAN \& G. W. MINSHALL. 1983. Methods for evaluating stream, riparian and biotic conditions. USDA, 33pp. 
POFF, N. L. \& J. V. WARD. 1989. Implications of streamflow variability and predictability for lotic community structure: a regional analysis of streamflow patterns. Can. J. Fish.Aquat. Sci., 46: 1805-1818

PUCKRIDGE, J. T., K. F. SHELDON, K. F. WALKER \& A. J. BOULTON. 1998. Flow variability and ecology of large rivers. Marine and Freshwater Research, 49: 55-72

SEDELL, J. R., G. H. REEVES, F. R. HAUER, J. A. STANFORD \& C. P. HAWKINS. 1990. Role of refuge in recovery from disturbances: modern fragmented and disconnected river systems. Environmental Management, 14: 711-724

STANLEY, E. H., S. G. FISHER \& N. B. GRIMM. 1997. Ecosystem expansions and contraction in streams. BioScience, 47: 427-435

STATZNER, B., K. HOPPENHAUS, M. F. ARENS \& P. RICHOUX. 1997. Reproductive traits, habitat use and templet theory: a synthesis of world-wide data on aquatic insects. Freshwat. Biol., 38: 109-135
STATZNER, B., V. H. RESH \& S. DOLÉDEC. 1994. Ecology of the Upper Rhône River: a test of habitat templet theories. Freshwat. Biol., 31: 253-556

STRICKLAND, J. D. H. \& T. R. PARSONS. 1972. A practical handbook of seawater analysis. Fish. Res. Bd. Can., 167 (2 $2^{\text {nd }}$ ed.): $311 \mathrm{pp}$

TOWNSEND, C. R., S. DOLÉDEC \& M. R. SARSBROOK. 1997. Species traits in relation to temporal and spatial heterogeneity in streams: a test of habitat templet theory. Freshwat. Biol., 37: 367-387

WELCH, P. S. 1948. Limnological methods. McGraw-Hill Internat. Ed. 381 pp.

WILLIAMS, D. D. \& B. W. FELTMATE. 1992. Aquatic insects. C. A. B. International, 358 pp.

WINTERBOTTOM, J. H., S. E. ORTON, A. G. HILDREW \& J. LANCASTER. 1997. Field experiments on flow refugia in streams. Freshwat. Biol., 37: 569-580. 
